\title{
ANÁLISIS DE CÓDIGOS ÉTICOS DEL ÁMBITO PUBLICITARIO
}

\section{ANALYSIS OF ETHICAL CODES OF ADVERTISING FIELD}

\section{AUTOR}

María Teresa Pellicer Jordá: Investigadora doctora de la Facultad de Comunicación y Documentación de la Universidad de Murcia.

maitepj@hotmail.com

\section{RESUMEN}

La publicidad es atacada de forma constante desde diversos frentes, pero casi todas las críticas hacen referencia a su vertiente ética. Por esta razón queremos estudiar y analizar el marco ético publicitario y poner de manifiesto sus puntos fuertes y débiles. De esta manera podremos enjuiciar de manera justa a la publicidad desde el punto de vista moral y ético. Con este objetivo, vamos a analizar diversos códigos deontológicos del ámbito publicitario, los cuales están vigentes en la actualidad. De este análisis obtendremos también una comparativa entre todos ellos para conocer, finalmente, los principios que conforman la ética publicitaria.

\section{PALABRAS CLAVE}

Publicidad - Ética - Deontología - Códigos - Regulación

\section{ABSTRACT}

The advertising is attacked of constant form from diverse fronts, but almost all the critiques refer to his ethical slope. For this reason we want to study and to analyze the ethical advertising frame and to reveal his strong and weak points. Hereby we will be able to judge in a just way to the advertising from the moral and ethical 
point of view. With this aim, we are going to analyze diverse codes of practice of the advertising area, which are in force at present. Of this analysis we will obtain also the comparative one between all of them to know, finally,the beginning that shape the advertising ethics.

\section{KEY WORDS}

Advertising - Ethics - Business ethics - Codes - Regulation

\section{ÍNDICE}

1. PRESENTACIÓN

2. CÓDIGO DE CONDUCTA PUBLICITARIA

2.1 Principios

2.2 Reflexiones

3. CÓDIGO ÉTICO DEL COMERCIO ELECTRÓNICO Y LA PUBLICIDAD INTERACTIVA

2.1 Principios

2.2 Reflexiones

$\boldsymbol{\sim} 4$. CÓDIGO DE AUTORREGULACIÓN PUBLICITARIA DE LA FEDERACIÓN DE BEBIDAS ESPIRITUOSAS

2.1 Principios

D.2 Reflexiones

5. CÓDIGO DE AUTORREGULACIÓN PUBLICITARIA DE CERVECEROS DE ESPAÑA

2.1 Principios

2.2 Reflexiones

6. CÓDIGO DE AUTORREGULACIÓN DEL VINO EN MATERIA DE COMUNICACIONES COMERCIALES

2.1 Principios

2.2 Reflexiones

7. CÓDIGO DEONTOLÓGICO PARA LA PUBLICIDAD INFANTIL

2.1 Principios

2.2 Reflexiones

8. CÓDIGO DE AUTORREGULACIÓN DE LA PUBLICIDAD DE ALIMENTOS DIRIGIDA A MENORES, PREVENCIÓN DE LA OBESIDAD Y SALUD

2.1 Principios

2.2 Reflexiones

9. CÓDIGO ÉTICO PARA LOS MIEMBROS DE ANDEMA 
2.1 Principios

2.2 Reflexiones

10. OROS CÓDIGOS ÉTICOS

11. COMPARATIVA ENTRE LOS DISTINTOS CÓDIGOS ÉTICOS

12. ELABORACIÓN DE NUESTRO PROPIO CÓDIGO ÉTICO PARA LAS COMUNICACIONES COMERCIALES

13. BIBLIOGRAFÍA

\section{PRESENTACIÓN}

La forma principal en la que se interrelacionan ética y publicidad es en forma de sistemas de autorregulación publicitaria. Con ellos se pretende establecer una serie de normas éticas y morales que rijan esta actividad. Estos sistemas de autorregulación se suelen traducir, en la práctica, en la creación de códigos deontológicos. Cada sector publicitario elabora el suyo propio, de acuerdo a los criterios que considera oportuno. Antes de conocer con detalle estos códigos, vamos a centrarnos en los sistemas de autorregulación de forma genérica, ya que, al fin y al cabo, los códigos son la materialización de los mismos.

Lo primero que debemos hacer es definir qué es un sistema de autorregulación. Para ello, usaremos el criterio y las definiciones de diversos autores relacionados con este campo y que plasmamos a continuación:

José Ramón Sánchez Guzmán: La autorregulación ${ }^{1}$ de la publicidad, dictada voluntariamente por los propios profesionales, constituye el reconocimiento profundo de la responsabilidad que su actividad tiene para con la sociedad donde incide y debe contemplarse como la respuesta de una profesión a las actitudes de esa sociedad frente a determinadas manifestaciones publicitarias.

1 Sánchez Guzmán, José Ramón: Teoría de la Publicidad. Madrid. 1993. Editorial Tecnos. Pág. 514. 
Enrique Ortega: Las normas ${ }^{2}$ de autodisciplina o autorregulación están formadas por diversas reglas y códigos deontológicos de actuación a los que voluntariamente pueden someterse los diferentes agentes que participan en esa actividad.

Autocontrol: La autorregulación $n^{3}$ es el compromiso de responsabilidad social de la industria publicitaria, que se manifiesta en el cumplimiento de determinados principios y normas deontológicas. (...)Es también un medio para procurar la pacífica y rápida resolución de controversias entre competidores.

Aznar: La autorregulación consiste en un conjunto de diferentes iniciativas, acuerdos, organismos, instituciones, etc- para los que usaremos en adelante el nombre genérico de mecanismos de autorregulación-, que poseen dos rasgos comunes: el objetivo de hacer efectiva la deontología de una determinada actividad o de contribuir a ello; y que quienes los crean y dan continuidad son los mismos agentes que llevan a cabo dicha actividad. Lo que sigue es una presentación de los diferentes mecanismos existentes en el ámbito de la comunicación, cada uno de los cuales posee un perfil, una historia, una función específicos ${ }^{4}$.

Haciendo un resumen de las definiciones planteadas podemos decir que la autorregulación supone:

- El reconocimiento de la responsabilidad social de cada profesión.

- La buena fe de sus profesionales, al cumplirlo de forma voluntaria.

\footnotetext{
2 Ortega, Enrique: La comunicación publicitaria. Madrid.2004. Editorial Pirámide. Pág. 345.

${ }^{3}$ Asociación para la Autorregulación de la Comunicación Comercial. Página web Autocontrol. Consultada 10-1-2010 en http://www.autocontrol.es
}

4 Aznar, Hugo: Comunicación responsable. Barcelona. 1999. Ariel. Pág. 12. 
- El establecimiento de la ética de la profesión, debido a ese carácter voluntario ${ }^{5}$.

- Un medio para solucionar controversias entre competidores.

- Las normas contempladas en estos sistemas nunca entrarán en conflicto con las leyes vigentes.

A estas características de los sistemas de autorregulación, debemos sumarle otra, también muy importante: no son exigibles judicialmente. Esto se deriva de su carácter ético y, por tanto, voluntario.

Lo cierto es que esos códigos de autorregulación se materializan en los códigos éticos. De ahí la necesidad de conocer primero el concepto y sus características, para después estudiar los códigos éticos concretos presentes en la publicidad española.

Comenzamos con las definiciones de código ético o deontológico planteadas por los distintos autores:

Hugo Aznar: Los códigos deontológicos ${ }^{6}$ son documentos que recogen un conjunto más o menos amplio de criterios, normas y valores que formulan y asumen quienes llevan a cabo una actividad profesional. (...) Los códigos deontológicos se ocupan de los aspectos más sustanciales y fundamentales del ejercicio profesional, aquellos que lo distinguen como tal y entrañan su específica dimensión ética.

FEBE (Federación Española de Bebidas Espirituosas) : Un código de autorregulación ${ }^{7}$ en materia de publicidad debe establecer un

\footnotetext{
${ }^{5}$ Aznar, Hugo: Comunicación responsable. Barcelona. 1999. Ariel. Pág. 325.

${ }^{6}$ Aznar, Hugo: Comunicación responsable. Barcelona. 1999. ArielPág. 17.

7 Código de la Febe. Página web Autocontrol . Consultada 6-1-2010 en http:/ / www.autocontrol.es/pdfs/pdfs_codigos/cod0017.pdf
} 
conjunto de principios y reglas de naturaleza deontológica, que siempre desde el respeto a la legislación vigente en la materia, precisen el sentido y alcance que tienen las normas legales aplicables $y$ especifiquen las conductas, prácticas y estrategias que, a la luz de las mismas, se consideren objetivamente conformes o disconformes con las exigencias de la buena fe y los buenos usos mercantiles.

Fernando Ramos: Los códigos ${ }^{8}$ deontológicos se ocupan un espacio intermedio entre las normas de carácter ético y las disposiciones normativas de carácter positivo, pero sin ser una cosa ni otra-aunque lo cierto es que las normas deontológicas se aproximan más a la ética que al derecho.

Bonete: Los códigos deontológicos ${ }^{9}$ vienen a expresar la conciencia moral que el colectivo profesional posee, la capacidad de asumir responsabilidades sociales y la sensibilidad ante la defensa de los derechos humanos fundamentales. (...) De hecho, los códigos deontológicos ${ }^{10}$, ante el relativismo moral reinante en las profesiones, vienen a recordarnos la validez objetiva de los mandatos universalizables que deben ser asumidos por quienes desempeñan actividades informativas y audiovisuales.

Jareño: Los códigos deontológicos ${ }^{11}$ no son sino la norma moral aplicada a un terreno profesional concreto. No se trata de una simple relación de deberes más o menos justificables en términos estrictamente prácticos. Es decir, la deontología no está unívocamente ligada al

\footnotetext{
8 Ramos, Fernando: La publicidad contaminada. Madrid. 2003. Universitas. Pág. 87.

9 Bonete, Enrique: Ética de la comunicación audiovisual. Madrid. 1999. Tecnos. Pág.31.

10 Bonete, Enrique: Ética de la comunicación audiovisual. Madrid. 1999. Tecnos. Pág.59.

11 Jareño, Joaquín: Ética y periodismo. Urduliz, País Vasco. 2009. Desclée. Pág. 147.
} 
consecuencialismo, aunque no deja de preocuparse de los resultados de la acción. Con el cumplimiento de las obligaciones profesionales buscamos hacer el bien, pero no únicamente en lo relativo a los beneficios que pueden derivarse de la profesión (...) sino igualmente para todos aquellos a quienes les afecte la actividad profesional.

Las definiciones de los códigos éticos cumplen fielmente con las características de los sistemas de autorregulación que establecíamos anteriormente: son normas de carácter ético, que respetan la legislación vigente y que muestran la conciencia y responsabilidad social del colectivo profesional, según destacan los distintos autores. Ahora bien no son exigibles judicialmente, algo que tiene una consecuencia directa: su ineficacia en muchos casos. Así se establece en el informe de la comisión especial sobre contenidos televisivos en el Senado, que data de 1995, donde se afirma lo siguiente:

El reproche unánime que suelen recibir los códigos deontológicos es, sin embargo, su ineficacia. Si la ley positiva se incumple, ¿cómo no se incumplirán los códigos que son más abstractos ${ }^{12}$ y generales $y$, además, carecen de sanciones? Pues efectivamente, la ley moral se distingue de la ley positiva en que aquella obliga en conciencia, no en virtud de que haya una autoridad que fuerce al cumplimiento y penalice su trasgresión. Los códigos deontológicos se han mostrado poco eficaces. Pero esa ineficacia tiene vías de solución o, por lo menos, de perfeccionamiento. Por una parte, los códigos elaborados hasta ahora adolecen de una falta esencial: tienden a un cierto corporativismo, han salido de la misma profesión, de los colegios profesionales. Es preciso perfeccionar los códigos deontológicos, haciéndolos menos proclives al corporativismo y a la endogamia profesional.

\footnotetext{
12 Bonete, Enrique: Ética de la comunicación audiovisual. Madrid. 1999. Tecnos. Pág.231.
} 
Frente a esta valoración negativa que se desprende de este informe, encontramos otras posturas que, por el contrario, valoran el hecho de que los códigos éticos no sean exigibles judicialmente y se considera que en eso radica su verdadero valor. Es el caso de Ortega, que considera que "aunque ${ }^{13}$ no tiene fuerza legal, sus efectos pueden llegar a ser más beneficiosos que los producidos por las normas jurídicas, ya que entrañan un compromiso voluntario de comportamiento por parte de los actores de la actividad publicitaria". Jareño añade que "la alternativa14 de exigir responsabilidad jurídica por no cumplirlos devalúa la importancia existencial de las obligaciones y la implicación real de los profesionales".

Sin duda, esta cuestión es una de las más polémicas acerca de los códigos deontológicos, al margen de las normas de comprendan, ya que, como se afirma en el informe, éstos suelen provenir de la propia profesión, por lo que su eficacia real en la sociedad está más que cuestionada. De ahí que se proponga la participación los propios ciudadanos. También es cierto que, en teoría, como afirma Ortega, los beneficios de estos códigos podrían ser extraordinarios, aunque en la mayoría de las ocasiones no sea así, como iremos comprobando. En cualquier caso, ésta y otras críticas, al igual que sus ventajas, las pondremos de manifiesto con más precisión en el análisis de los distintos códigos éticos estudiados.

$\underline{\text { Aclaraciones previas sobre el análisis de los códigos éticos de la publicidad española. }}$

El primer aspecto que debemos resaltar es que en todos los códigos éticos que vamos a analizar es el jurado de Autocontrol el encargado de dirimir los conflictos que surjan en esta materia, ya que estos códigos han sido redactados por ellos en colaboración con los sectores implicados. De hecho, se contemplan sanciones, basadas fundamentalmente en

\footnotetext{
13 Ortega, Enrique: La comunicación publicitaria. Madrid.2004. Editorial Pirámide. Pág. 325.

14 Jareño, Joaquín: Ética y periodismo. Urduliz, País Vasco. 2009. Desclée. Pág. 147.
} 
la rectificación o cesación de esa publicidad concreta, la cual podrá ser solicitada por cualquier interesado, ya se particular, empresa, asociación de consumidores, etc.

En segundo lugar, y con el fin de facilitar la comparación entre los mismos, hemos establecido unas categorías o principios generales en los que englobar cada uno de los principios concretos que se recogen en estos códigos. Como veremos más adelante, no en todos los códigos están presentes estas categorías. La clasificación es la siguiente:

- Respeto a la ley vigente

- Respeto y protección del consumidor

- Características del mensaje

- Interpretación de la publicidad

- Normas de inserción de los anuncios

- Respeto al medio ambiente

- Relación con otras empresas del mercado, que incluye la publicidad comparativa.

- Protección de niños y adolescentes

En tercer lugar, destacar que estos códigos son de aplicación exclusiva a la comunicación comercial a la que se refiere cada uno de ellos. Por tanto, la publicidad política no queda sometida a ellos.

En cuarto lugar, no siempre citaremos todos los principios establecidos en cada código, sólo lo haremos con aquellos relacionados con nuestro tema de estudio: las cuestiones éticas en la publicidad. 


\section{Código de Conducta Publicitaria}

El Código de Conducta Publicitaria ${ }^{15}$ fue aprobado en la Asamblea General Extraordinaria del día 19 de diciembre de 1996, según lo establecido en los estatutos de la Asociación para la Autorregulación de la Comunicación Comercial, más conocida como Autocontrol. El 3 de abril de 2002 se introdujeron algunas modificaciones, que están contempladas en esta versión del código.

El Código de Conducta Publicitaria se articula en dos capítulos. El primero de ellos aborda el ámbito de aplicación y las normas generales, mientras que el segundo trata sobre las normas deontológicas. En relación con el ámbito de aplicación, el código establece que "estas normas deontológicas se aplican a toda actividad de comunicación publicitaria tendente a fomentar, de manera directa o indirecta y sean cuales fueren los medios empleados, la contratación de bienes o servicios, o el potenciamiento de marcas y nombres comerciales. También serán aplicables las presentes normas deontológicas a cualquier anuncio emitido por cuenta de cualesquiera personas físicas o jurídicas, de carácter privado, con el fin de promover determinadas actitudes o comportamientos. No serán de aplicación a la publicidad política".

\subsection{Principios}

En total son 29 los principios establecidos, que a continuación pasamos a analizar según el modelo establecido anteriormente:

Respeto a la ley vigente.

15 Código de conducta publicitaria. Página web Autocontrol. Consultada 20-1-2010 en

http://www.autocontrol.es/pdfs/Cod_conducta_publicitaria.pdf 
De esta forma, establece que "la publicidad debe respetar la legalidad vigente y, de manera especial, los valores, derechos y principios reconocidos en la Constitución (art. $2)^{\prime \prime}$.

Respeto y protección al consumidor:

- En este código se establece el derecho al honor, intimidad y propia imagen (art. 11).

- "La publicidad no deberá constituir nunca un medio para abusar de la buena fe del consumidor" (art. 4).

- “La publicidad no ofrecerá argumentos que se aprovechen del miedo, temor o supersticiones del destinatario (art. 5)". Respecto a esta idea, el código ético introduce una aclaración: “Los anunciantes podrán recurrir al miedo, siempre proporcionado al riesgo, para alentar un comportamiento prudente o desalentar acciones peligrosas, imprudentes o ilegales". Este último es el caso de la estrategia que se sigue en las campañas de la Dirección General de Tráfico, por ejemplo. Añade que, "la publicidad no sugerirá circunstancias de discriminación (art. 10), ya sea por razón de raza, nacionalidad, religión, sexo u orientación sexual, ni atentará contra la dignidad de la persona".

Características del mensaje.

- La publicidad no incitará a la violencia (art. 6), a comportamientos ilegales (art. 7) o a prácticas peligrosas (art. 9).

- “La publicidad no deberá incluir contenidos que atenten contra los criterios imperantes del buen gusto y del decoro social, así como a las buenas costumbres (art. 8)".

- La publicidad debe ser identificable (art. 13) y no debe ser engañosa, (art. 14), entendiendo por engañosa aquella publicidad que pueda inducir a error a sus destinatarios. En este sentido, se exige que el mensaje completo sea 
comprensible pero debe serlo especialmente en lo relativo al origen, naturaleza, composición, disponibilidad, fecha de caducidad y de fabricación, precio, resultados de la utilización del producto y de los riesgos que conlleva su utilización, entre otros.

- "La referencia a la novedad debe expresar si se trata de una novedad en el mercado o si se trata de una novedad de los productos del anunciante" (art. 14-f).

- En este código también se regulan los distintos tipos de informaciones que acompañan al anuncio y cuya función es convencer al consumidor de la conveniencia de utilizar un producto determinado. Es el caso de los datos técnicos, científicos o estadísticos que se pueden encontrar en muchos anuncios (art. 17). El código establece que estos datos "deben ser relevantes, comprobables y no deben inducir al error". También se hace referencia a la difusión de ensayos comparativos de productos y servicios (art. 18). En tal caso el código propugna la revelación de la persona física o jurídica que los haya hecho, así como la fecha de realización de éstos. Respecto a los testimonios (art. 19), se afirma que "cuando la publicidad incluya recomendaciones y testimonios se deberá responder a la verdad".

- "Nadie puede sugerir, en su publicidad, que su producto o servicio posee características particulares cuando éstas sean comunes entre los productos o servicios similares. (art. 26- Principio de Carácterísticas comunes).

Respeto al medio ambiente.

Este código establece que "la publicidad no incitará ni alentará comportamientos que perjudiquen el medio ambiente" (art. 12).

Interpretación de los anuncios y valor de la publicidad. 
En este código se resalta el valor de la publicidad (art. 1) y se establece como debe interpretarse la misma (art. 3): “Los anuncios y las expresiones publicitarias deben ser analizadas en su conjunto, sin descomponer sus partes integrantes y atendiendo a la impresión global que generen en sus destinatarios", aunque se aclara que "podrán ser objeto de análisis específico aquellas partes que, por aparecer de forma especialmente destacada, capten principalmente la atención del consumidor".

Relación con otras empresas del mercado.

- “La publicidad no deberá contener referencias a los signos distintivos de otro anunciante" ni de otros anuncios (art. 20).

- "La publicidad no deberá denigrar ni menospreciar a otras empresas, actividades, productos o servicios (art. 21)". En este sentido se añade que "no se considerarán denigración las manifestaciones recogidas en el mensaje publicitario que sean exactas, verdaderas y pertinentes". Se pone de manifiesto que "deberá apoyarse en características esenciales, afines, análogas y objetivamente demostrables" y añade que "en todo caso esta publicidad responderá a la verdad y no se expresará en términos engañosos o denigrantes". Eso sí, el código establece que "si se trata de comparaciones entre productos o servicios, no se admitirá en ningún caso la comparación con otros no similares o desconocidos o de limitada participación en el mercado" (art. 22).

Protección de niños y de adolescentes.

En este código se afirma que "la publicidad dirigida a niños deberá ser extremadamente cuidadosa" y que ésta "no debe explotar la ingenuidad, inmadurez e inexperiencia de los niños, ni abusar de su sentido de la lealtad. Además, la publicidad dirigida a niños no deberá "contener declaraciones o presentaciones visuales que puedan producirles perjuicio mental, moral o físico" y no se deben emitir informaciones que induzcan a engaño (art. 28). 


\subsection{Reflexiones sobre del Código de Conducta Publicitaria}

Tras estudiar los principios recogidos en este código, podemos afirmar que es un código bastante completo a nuestro juicio, ya que recoge los principales rasgos que deben ser controlados en la publicidad, tales como el respeto al consumidor, a la legalidad vigente, al medio ambiente o a otras empresas del mercado... Incluso regula las características del mensaje en cuanto a moralidad e información que se ofrece en el mismo, la publicidad engañosa y el derecho al honor y a la integridad de la persona. Lo cierto es que si estos principios son básicos en la defensa del consumidor, el código contempla otros que debemos comentar por su trascendencia.

En primer lugar, en este código se establece que la publicidad no debe abusar de la buena fe del consumidor ni de sus temores y miedos, un aspecto que es necesario resaltar en los tiempos que corren. El por qué lo hemos estado esbozando a lo largo de toda esta investigación. De este modo, es patente en cualquier anuncio, que se intenta vender al consumidor cosas inmateriales que nada tienen que ver con el producto o servicio que anuncia. Esto es, sueños, ilusiones, éxito social, felicidad, eterna juventud. Pero es más, resaltamos el aspecto de los temores porque la publicidad se aprovecha del temor de la población al rechazo social, la infelicidad, la frustración, etc, y es por ello por lo que utiliza estos conceptos o productos, llamémosles así, inmateriales como principal argumento de venta, quedándose el producto material en ocasiones como envoltorio de esas ansiadas sensaciones prometidas en los anuncios. De esta manera, y volviendo a los principios de este código, consideramos que eso es publicidad engañosa, porque no se puede vender la felicidad ni el éxito. Es más, hay un principio específico, llamado 'Características comunes', en el que se establece que no se podrán sugerir características particulares cuando son, realmente, comunes al resto de productos similares. Eso mismo, es decir, atribuir características particulares,- es decir, la venta de sueños, felicidad, etc- es lo que hace la publicidad actual, ya que las diferencias físicas y comprobables con el resto de los productos similares son prácticamente inexistentes. 
Existe otro principio establecido en este código que nos permite hacer el análisis que estamos realizando a lo largo de este trabajo y es el que dice que la interpretación de los anuncios debe hacerse de forma global y analizando aquellas partes que capten principalmente la atención del consumidor. Eso mismo es lo que nosotros estamos haciendo, ya que esa venta de sueños y, en definitiva, conceptos inmateriales son los que captan la atención del consumidor principalmente.

Por otra parte, es preciso resaltar la defensa que hace este código de los menores y su condena de aquellos anuncios que explotan su inmadurez e inexperiencia y, en definitiva, sus características de niños para vender productos.

Aún considerando éste un código muy completo, debemos poner de manifiesto dos carencias. En primer lugar resaltamos que no contempla los casos de publicidad subliminal, ni normas sobre la inserción de los anuncios en los medios de comunicación. En segundo lugar, los supuestos en los que este código ha establecido estos principios parecen basarse en cuestiones físicas y no en los conceptos inmateriales que nosotros resaltamos y que están tan presentes en la publicidad actual. En cualquier caso, esta última afirmación es una apreciación personal, ya que no conocemos, ni se pone de manifiesto en ningún momento en este código esta distinción entre cuestiones inmateriales e inmateriales.

\section{CÓDIGO ÉTICO DEL COMERCIO ELECTRÓNICO Y LA PUBLICIDAD INTERACTIVA}

El Código de Comercio Electrónico y Publicidad Interactiva ${ }^{16}$ entró en vigor en enero del año 2003. Entre noviembre de 2004 y junio de 2005 sufrió varias

16 Código ético de comercio electrónico. Página web Autocontrol. Consultada 25-1-2010 en

http://www.autocontrol.es/pdfs/Cod_ConfianzaOnline.pdf 
modificaciones con el fin de adaptarlo a los requisitos del Real Decreto 292/2004, por el que se crea el Distintivo Público de confianza en los nuevos medios electrónicos. El 15 de julio de 2005, el Instituto Nacional de Consumo le otorgó el ‘Distintivo Público.

Respecto a los orígenes de este código, responde a la iniciativa de dos asociaciones, AECE (Asociación Española del Comercio Electrónico) y AUTOCONTROL (Asociación para la autorregulación de la Comunicación Comercial). El objetivo era "aunar los esfuerzos de ambas entidades para establecer un sistema de autorregulación integral que se beneficiara de las especializaciones y recursos respectivos. Con todo ello se evitaba la aparición de diferentes sistemas de autorregulación dispersos con el riesgo de crear confusión en los consumidores y en el mercado", como se explica en este código. A este proyecto se han adherido otras asociaciones como IAB (Interactive Adevertising Bureau Spain), AEA (Asociación Española de Anunciantes), ACM (Asociación de Centrales de Medios), FECEMD (Federación Española de Comercio Electrónico y Marketing Directo), AGEMDI (Agencias de Marketing Directo e Interactivo), FNEP (Federación Nacional de Empresas de Publicidad) y ASIMELEC ( Asociación Multisectorial de Empresas Españolas de Electrónica y Comunicaciones).

El Código Ético del Comercio Electrónico y la Publicidad Interactiva se articula en 7 capítulos y dos disposiciones, lo que supone en total 37 principios. De ellos, a nosotros nos interesan los primeros trece capítulos, ya que tratan sobre la publicidad, y el artículo 29, que habla sobre la protección de los menores. 


\subsection{Principios del Código ético del comercio electrónico y la publicidad interactiva}

Como decíamos, de los 37 principios que se establecen en este código, nosotros vamos a estudiar los catorce que hacen referencia a la publicidad y sus formas. De acuerdo con el esquema de análisis establecido, distinguimos los siguientes:

Respeto a la ley vigente.

Este código establece que "la publicidad en medios electrónicos de comunicación a distancia deberá ser conforme a la ley aplicable, decente, honesta y veraz (art. 3.1)".

Respeto y protección al consumidor.

- Este tipo de publicidad "deberá ser elaborada con sentido de la responsabilidad social (art. 3.3) y no deberá constituir nunca un medio para abusar de la buena fe de sus destinatarios".

- "La publicidad en medios electrónicos a distancia no tendrá contenidos que atenten contra la dignidad de la persona o sean discriminatorios (art. 3.4) (por razón de nacionalidad, raza, sexo, orientación sexual, convicciones religiosas o políticas o cualquier otra circunstancia personal o social) o que inciten a la comisión de actos delictivos".

Características del mensaje.

- Este texto ético propone la identificación del anunciante (art. 4), así como la identificación del espacio publicitario, es decir, debe indicarse de forma clara que es publicidad y no información. Condena la publicidad encubierta. 
- Se propone que se debe proporcionar al destinatario toda aquella información sobre el producto o servicio (art. 5) que pueda serle de utilidad, tal como el precio del producto o la dirección de la empresa, entre otros. Junto a ello, "se debe informar sobre el precio para acceder a un mensaje o servicio cuando éste sea mayor que las tarifas básicas de comunicación".

- Se contempla los casos de promociones publicitarias (art. 6), patrocinios (art. 13) y establece que "no se admitirá el envío de publicidad mediante mensajes de correo electrónico u otros medios de comunicación individual equivalentes por parte del anunciante cuando no haya sido solicitada o autorizada expresamente por el destinatario (art. 9 y 10 )" y añade que "la publicidad no podrá impedir la libre navegación del usuario en Internet" (art. 12).

Relación con otras empresas del mercado.

Se establece el respeto de los derechos de propiedad intelectual y los casos de competencia desleal (art. 8).

Protección de niños y adolescentes.

En este código se hace una referencia explícita a la protección de menores (art. 29). Así, establece que "la publicidad difundida en medios electrónicos de comunicación a distancia no deberá perjudicar moral o físicamente a los menores". Además, se introducen varias especificaciones. Una de ellas es que "se deberá identificar los contenidos dirigidos únicamente a adultos" y no se "deberá incitar directamente a los menores a la compra de un producto o servicio, explotando su inexperiencia o su credulidad, ni a que persuadan a sus padres o tutores para que compren los productos 
o servicios de que se trate". Añade que "no deberá, sin motivo justificado, presentar a los niños en situaciones peligrosas".

\subsection{Reflexiones sobre el Código Ético del Comercio Electrónico y la Publicidad Interactiva}

En este código se establece el respeto a la legalidad y de la buena fe del consumidor, el concepto de responsabilidad social, la necesidad de identificar bien la publicidad, que debe ser honesta y veraz y el respeto a la infancia. Los argumentos que ofrecen en estos puntos son similares a los ofrecidos en el Código de Conducta Publicitaria, que es bastante más completo que éste. En cualquier caso, resaltamos el hecho de que sí establece ciertas normas de inserción de los anuncios en Internet, aunque serían necesarias normas más específicas en este sentido.

Respecto a sus carencias, destacamos que no contempla los casos de publicidad subliminal- aunque éste no es un aspecto contemplado en los códigos porque ya está penado por la Ley General de Publicidad- o el respeto por el medio ambiente. Echamos en falta también el establecimiento de criterios acerca de cómo deben interpretarse los anuncios.

Por tanto, podemos decir que este código es una versión reducida del Código de Conducta Publicitaria y que las carencias que tiene serán comunes al resto de códigos que analizaremos. 


\section{Código de autorregulación publicitaria de la Federación Española de Bebidas Espirituosas}

La Federación de Bebidas Espirituosas ${ }^{17}$ (FEBE) engloba a más de 150 empresas productoras y distribuidoras en España de bebidas espirituosas y productos derivados. Este código deontológico fue aprobado inicialmente el 16 de diciembre de 1999. El 14 de febrero de 2006 fue revisado y actualizado.

En el preámbulo de este código se dan algunas de las razones de su creación:

- La producción y consumo de bebidas espirituosas tiene un fuerte arraigo económico y social en la cultura occidental, formando parte de ella.

- La FEBE tiene como una de sus misiones principales promover la responsabilidad social activa del sector, contribuyendo, en colaboración con las autoridades y el conjunto de la sociedad, a luchar contra el consumo abusivo de bebidas alcohólicas, a prevenir su consumo en colectivos o situaciones de riesgo (menores, conductores, mujeres embarazadas, etc) y a promover la responsabilidad, moderación y sensatez en el consumo de bebidas alcohólicas por el resto de la población.

- Las experiencias de prohibición total de publicidad de bebidas espirituosas han demostrado su falta absoluta de eficacia y de resultados para evitar su uso abusivo y del alcoholismo". Consideran que, "por el contrario, las

${ }^{17}$ Código de la Febe. Página web Autocontrol . Consultada 6-1-2010 en http:/ / www.autocontrol.es/pdfs/pdfs_codigos/cod0017.pdf 
campañas informativas, así como la educación en el entorno social, constituyen el medio más eficaz para la concienciación de los ciudadanos en relación con estos problemas, y que a tal efecto la publicidad puede ser utilizada como un vehículo privilegiado para la difusión de mensajes destinados al fomento del consumo moderado y responsable".

- La publicidad constituye un elemento esencial en la configuración de la libre competencia.

- Los sistemas de autorregulación en el ámbito de la publicidad y las comunicaciones comerciales vienen gozando de un considerable y creciente reconocimiento, por parte tanto de instancias comunitarias como del legislador nacional, que animan e impulsan la elaboración de códigos de conducta por parte de todas las partes implicadas.

Este código es aplicable a la "publicidad de la bebidas espirituosas y las bebidas a base de espirituosos, y/o que se encuentren en el ámbito objetivo del Impuesto sobre el alcohol y a las bebidas derivadas, elaboradas, comercializadas o importadas por las empresas asociadas a la FEBE". En todo caso, se excluye la cerveza, la sidra y los productos del sector vitivinícola, que cuentan con sus propios códigos de regulación.

El código se articula de la siguiente forma: preámbulo y seis capítulos, que engloban 17 artículos, que pasamos a analizar. 


\subsection{Principios del Código de Autorregulación Publicitaria de la Federación de} Bebidas Espirituosas

A continuación vamos a analizar los artículos que engloba el Código de Autorregulación de la Federación Española de Bebidas Espirituosas, de acuerdo al modelo ya establecido anteriormente:

Respeto a la ley vigente Este código establece que "la publicidad de las bebidas a las que se aplica se ajustará a la legislación vigente, cualquiera que sea su contenido, el medio de difusión o la forma que adopte" (art. 4 ).

Respeto y protección al consumidor:

En este código no encontramos referencias directas sobre el derecho al honor y respeto al consumidor, pero estos aspectos se pueden desprender de otros artículos que hemos insertado en otros puntos, tales como la defensa de una publicidad honesta y veraz.

Características del mensaje.

- La Publicidad a la que se aplica este Código será veraz e identificable como tal (art. 6 ) y añade que debe indicarse con claridad la graduación de la bebida alcohólica.

- Se establece que no podrá fomentar el abuso del consumo y que la publicidad siempre se realizará en términos de responsabilidad social, incluyendo el mensaje de consumo responsable (art. 7 y 13 ). En este mismo artículo se establece las características físicas que debe cumplir ese mensaje de consumo responsable. Establece que ocupará un uno por ciento de la superficie del anuncio y debe ser claramente legible, entre otras medidas. En este código se afirma que "la publicidad de bebidas a las que se aplica este código podrá realzar el placer de la comunicación, convivencia o 
confraternización social asociado al consumo responsable pero nunca podrá sugerir que el no consumir es sinónimo de inmadurez, de fracaso en la vida social o laboral o en los negocios o que los no consumidores son menos aceptados o tienen menos éxito que los consumidores". Además, "no podrá sugerir que el consumo puede contribuir al éxito sexual o laboral, a incrementar el atractivo sexual o a superar la timidez". Añade que no se podrán mostrar situaciones en las que el consumo en solitario contribuya a solucionar problemas de inadaptación social, de ansiedad u otros conflictos internos y tampoco se podrán mostrar situaciones en las que el consumo aumente el rendimiento físico o mental. No se le podrán atribuir la posibilidad de curar enfermedades o indicar sus propiedad terapéuticas (art. 8). En este mismo artículo es establece que "no se asociará las bebidas con situaciones de violencia, peligro o comportamientos antisociales", así como situaciones de peligro. Además, no se "podrán presentar situaciones de abuso en el consumo de este tipo de bebidas" y no "podrá mostrar imágenes de la mujer con carácter discriminatorio o vejatorio, ni imágenes femeninas estereotipadas que puedan generar violencia".

- "La publicidad de las bebidas a las que se aplica este código no podrá sugerir que se puede consumir un mínimo de alcohol sin peligro para la conducción y la seguridad vial, ni tampoco se mostrarán situaciones asociadas con la conducción de vehículos, excepto en los casos de campañas dirigidas concienciar y a responsabilizar a la sociedad de los riesgos derivados del abuso en el consumo de tales bebidas". Añade que "no se podrá insertar publicidad en revistas $u$ otras publicaciones de motor o en aquellos suplementos o secciones especializadas de revistas $\mathrm{u}$ otras publicaciones cuyo contenido mayoritario sea el motor (art. 9).

Normas sobre la inserción de los anuncios. 
Junto a las normas sobre la inserción que se han citado en otros artículos, que hemos englobado en apartados anteriores, el códio establece una serie de normas sobre la inserción de los anuncios, especialmente en lo referido a los menores. De este modo, en el artículo 10 se afirma que:

- "La publicidad directa y, en particular el envío de folletos, publicidad gráfica y otros soportes publicitarios por cualquier medio a un consumidor o conjunto de consumidores determinados se dirigirá en todo caso a personas mayores de edad y, a tal efecto, en su presentación exterior hará constar el nombre e la persona mayor de edad a la que se dirige y en su contenido interno incluir la leyenda 'No válido para menores' (art. 10 ).

- “No se podrá insertar publicidad en televisión, radio o cine durante, inmediatamente antes o inmediatamente después de programas o sesiones específicamente dirigidos o cuya audiencia está especialmente constituida por menores".

- “No se podrá insertar publicidad en televisión hasta el momento de arranque de los informativos de la tarde noche y en ningún caso antes de las 20:30 horas".

- "No se podrá insertar publicidad en publicaciones dirigidas a menores o en las páginas para menores de publicaciones no específicamente dirigidas a éstos".

Relación con otras empresas del mercado.

- La Publicidad de las bebidas a las que se aplica este Código se ajustará a las exigencias de la buena fe y los buenos usos mercantiles, cualquiera que sea su contenido, el medio de difusión o la forma que adopte (art. 5 ).

- No podrá utilizar una denominación social, nombre comercial y otro signo distintivo sustancialmente idéntico a una marca cuya publicidad está 
prohibida en el medio a través del cual se pretende difundir, salvo en los supuestos contemplados en este artículo (art. 11).

Protección de niños y de adolescentes.

En este código se establece que "la publicidad no podrá dirigirse específicamente a los menores de edad, a mujeres embarazadas o a personas con bajo tratamiento médico" y tampoco podrá mostrar imágenes, dibujos, iconos, personajes de ficción o a personas de relevancia pública directamente vinculados con menores de edad. Añade que "los modelos de publicidad a la que se aplica este código no deberán ser menores de 23 años" (art. 10).

\section{2. Reflexiones sobre el Código de Autorregulación Publicitaria de la Federación de} Bebidas Espirituosas

A primera vista, podemos decir que es un código completo, que recoge todas las categorías establecidas por nosotros, excepto la relativa al medio ambiente- y que expresa con bastante exactitud sus normas. De esta forma, encontramos en el mismo los principios de respeto a la legalidad vigente, el establecimiento de ciertas características que debe cumplir el mensaje, el respeto a la infancia, normas de inserción sobre los anuncios o el principio de competencia leal con otras empresas del mercado. Ahora bien, debemos hacer matizaciones en cada de estos puntos.

En primer lugar, vemos como no hay una referencia directa a la protección del consumidor. A pesar de ello, nosotros hemos considerado que en cierto modo, y aún sin esas referencias expresas a su honor, sí está reflejado cuando apuesta por una

publicidad honesta y veraz. A pesar de ello, consideramos que deberían hacerse referencias más explícitas en este sentido, lo que supondría una mayor defensa del consumidor. 
En segundo lugar, este código contempla que no se asociará el consumo de este tipo de bebidas con el éxito en la vida, ni transmitirá que quien no las consuma estará avocado al fracaso en general, pero a su vez, establece que "se podrá realzar el placer por la comunicación, la convivencia y la confraternización social". Estos dos aspectos son contrapuestos, ya que si se plasma esa confraternización social, como ellos le llaman, se está dejando entrever que el consumir ese producto da lugar a esa situación o que en esas situaciones lo ideal es consumir ese producto. Esto es como la diferencia entre las expresiones 'está mal' y 'no está muy bien'. Se quiere decir lo mismo con las dos pero una es más suave que la otra. Un caso similar encontramos en este código, lo que calificamos de contradicción clara, ya que en cualquier anuncio de este tipo de productos se muestran a personas con éxito social, laboral o personal (chicas y chicos guapos, grupos de amigos, gente de clase media alta, situaciones ocio y de diversión, etc) y se asocia con ellos ese producto. Es más, se explica que no podrá indicar que consumir estos productos aumenta el éxito sexual o hace superar la timidez, cuando en los anuncios vemos a chicos guapísimos que ligan con chicas guapísimas, e incluso otros en los que los chicos se atreven a decirle a las chicas lo que sienten cuando están consumiendo ese producto.

En tercer lugar nos llama la atención el artículo en el que se afirma que no se usarán imágenes femeninas estereotipadas que puedan generar violencia. La pregunta que nos hacemos es qué significado tiene para este sector un estereotipo. Aparecen, de este modo, mujeres atractivas y sensuales, lo que se entiende por estereotipo. La parte que no entendemos bien es la violencia que se puede generar con ellas. En este sentido, también debemos destacar el principio que afirma que no se podrá mostrar imágenes de la mujer con carácter discriminatorio. La pregunta entonces es ¿qué es discriminatorio? ¿Una mujer con poca ropa y en posición sensual utilizada para vender un producto es discriminatorio o no? Lo cierto es que la mujer ha sido un recurso usado en muchos anuncios de bebidas espirituosas, que ya en el mismo nombre indica algo relativo al espíritu. Se la utiliza como un reclamo, atribuyendo a esa bebida las características de la 
mujer que lo anuncia. Da la sensación en ese tipo de anuncios que una mujer tan maravillosa y perfecta como la que sale en la imagen se tiraría a los brazos de cualquier hombre que le invitara a una copa de esa marca o, al revés, que un hombre bebiendo una copa de esa marca conseguiría atraer a ese tipo de mujer o viceversa, la mujer atraería al hombre.

En cuarto lugar nos gustaría comentar el mensaje de consumo responsable que debe aparecer en todos los anuncios de este tipo. En este código se afirma que debe ser legible y visible, aunque la cuestión es cómo va a ser visible ocupando el uno o uno y medio por ciento de todo el anuncio. Además, se suele colocar en la parte inferior del anuncio, con lo que su visibilidad es aún menor en el caso de los soportes escritos y fijos. Una segunda cuestión, en el caso de las televisiones, este mensaje debe permanecer, al menos, dos segundos. Nosotros decimos entonces ¿realmente en un impacto tan corto, de dos segundos, uno puede leer bien lo que pone? No, de hecho pasará desapercibido, tanto por su tamaño como por su duración.

En quinto lugar, se pone de manifiesto que en los anuncios no se asociará la bebida con situaciones de violencia o de agresividad. En este sentido, debemos decir que, en muchos casos, la consecuencia del consumo de este tipo de productos es la violencia. Por tanto, más que una norma ética, esta premisa es una protección del propio producto, ya que se omite uno de los efectos directos que pueden tener las bebidas espirituosas.

En sexto lugar, propone que los anuncios de las bebidas espirituosas no se emitan en la franja infantil. El problema reside en que la franja infantil prácticamente no existe, ya que en muy pocas ocasiones hay una programación destinada especialmente a los más pequeños. Aun así, consideramos que es acertado establecer normas de inserción en este sentido. Algunas de ellas siguen vigentes, pero las relativas a la televisión dejaron de ser válidas desde la que franja infantil en los medios de comunicación dejó de existir en la práctica. 
En séptimo lugar, queremos destacar otras carencias que encontramos en este modelo: no se habla de la publicidad comparativa ni de la información se debe dar a consumidor sobre el producto. Además, no se trata el tema de la discriminación, excepto en el caso de las mujeres, como hemos visto en el segundo punto.

En octavo lugar, valoramos la inclusión de un apartado específico sobre la seguridad vial y la necesidad de separar alcohol y conducción.

Llegados a este punto de análisis de este código, encontramos un ejemplo de un código que ha sido hecho para mejorar su imagen social y con las instituciones- que recomiendan su elaboración-. No encontramos en él utilidad alguna, ya que se basa en justificar el tipo de anuncios que se están haciendo desde hace muchísimos años y que forman parte del grupo que nosotros consideramos no éticos, ya que se justifican esas características inmateriales inherentes al producto. Este código no está hecho con el objeto de beneficiar al consumidor, ni de hacer una publicidad ética, como hemos visto en sus continuas contradicciones entre sus propios artículos y con la realidad de los anuncios que más tarde analizaremos.

\section{Código de autorregulación publicitaria de cerveceros de España}

Este código fue aprobado en 199518, lo que lo convierte en uno de los primeros códigos en elaborarse en este campo de la ética en la publicidad comercial. El objetivo general del mismo es que todas las comunicaciones comerciales sobre cerveza sean "legales, honestas, legales, verídicas y acordes a los principios de justa competencia y buenas prácticas comerciales" y añaden que "en ningún caso transgredan los límites de la ética, la dignidad o la integridad humana".

18 Código de autorregulación publicitaria de cerveceros de España. Página web Autocontrol. Consultada 23-1- 2010 en http://www.autocontrol.es/pdfs/pdfs_codi-gos/cod0036.pdf 
Al igual que en el código de las bebidas espirituosas, se establece que las limitaciones en las comunicaciones comerciales de las bebidas alcohólicas han demostrado su falta de eficacia y de resultado para atajar los problemas derivados del abuso.

El código se articula en ocho capítulos y preámbulo, en los que se recogen los principios de este código.

\subsection{Principios del Código de Autorregulación Publicitaria de Cerveceros de España}

Respeto a la ley vigente.

En este código se establece respeto a la legalidad vigente (Preambulo).

Respeto y protección al consumidor.

En este código se establece el respeto y protección al consumidor, a juzgar por los principios establecidos, aunque no aparece ningún principio concreto de ello.

Características del mensaje.

- “Todas las comunicaciones comerciales, tanto en su contenido como en su forma y difusión serán realizadas con sentido de la responsabilidad social" (Cap. 2 ).

- “Las comunicaciones comerciales no describirán situaciones en las cuales se dé la impresión de un consumo abusivo y asociado al consumo de sustancia psicotrópicas y tabaco" y "no deberán mostrar a personas en estado de embriaguez (...) como actitud ejemplar positiva" (Cap. 3 ).

- "Las comunicaciones comerciales no indicarán que el consumo de cerveza contribuye a la disminución o desaparición de sentimientos de ansiedad, de conflictos internos o de sentimientos de inadaptación social como resultado 
de su consumo". Añade que "se podrá resaltar el placer de la comunicación, convivencia o confraternización social (...), pero nunca deberán implicar que beber es necesario para tener éxito en la vida social o en los negocios o que los no bebedores son menos aceptados o tienen menos éxito que los que sí lo son. Tampoco deberán fomentar actuaciones agresivas ni comportamientos violentos" (Cap. 3 ).

- “Las comunicaciones comerciales no reivindicarán o sugerirán que la cerveza puede contribuir al éxito o atractivo sexual, ni que pueda ayudar a superar la timidez" y añaden que no harán "referencias sexistas que desvirtúen el papel de la mujer en la sociedad" (Cap. 3 ).

- En este código se establecen también principios para separar conducción y cerveza (Cap. 5 ), al igual que trabajo (Cap. 6).

- “En las comunicaciones comerciales no habrá ningún tipo de referencia discriminatoria por razón de raza, orientación sexual, etc" (Cap. 3 ).

- En todos los anuncios se deberá incluir el mensaje sobre el consumo responsable, en un formato legible (letra 26). En el caso de los anuncios de televisión, éste deberá permanecer entre 3 y 10 segundos, según la duración del spot (Cap. 2 ).

Normas sobre la inserción de los anuncios.

- No se realizarán comunicaciones comerciales en portadas ni en contraportadas de los periódicos diarios (Cap. 2 ).

- También establece normas de inserción concretas para proteger a los menores (Cap. 4 ). 
Relación con otras empresas del mercado.

En el preámbulo se afirma que el objetivo de este código es que las comunicaciones de este tipo de productos sean "legales, honestas, legales, verídicas y acordes a los principios de justa competencia y buenas prácticas comerciales".

Protección de niños y de adolescentes.

- La publicidad de este tipo de bebidas no se dirigirá a menores de 18 años (Cap. 4$)$.

- Las comunicaciones comerciales no deberán sugerir que el consumo de cerveza es un signo de madurez y que el no beber es síntoma de inmadurez. Tampoco deben mostrar a personas que den la impresión de que ellos, cuando todavía eran menores de edad, consumían cerveza" (Cap. 4 ).

- Tampoco se podrán usar personajes vinculados al público infantil (Cap. 4 ).

\subsection{Reflexiones sobre el Código de Autorregulación Publicitaria de Cerveceros de España}

Al igual que ocurre con el caso anterior, el código de bebidas espirituosas, podemos decir a simple vista que este código es completo, en tanto en cuanto recoge la mayoría de las categorías que hemos establecido, pero analizándolas con detalle observamos algunas carencias que pasamos a comentar.

En primer lugar, en este modelo no se regula de forma precisa la publicidad comparativa o la información adicional que acompaña a los anuncios.

Además, aquí ocurre lo mismo que en el caso anterior y es que se establece que en los anuncios no se asociará la bebida con la agresividad y la violencia cuando éste es uno de los efectos que puede producir, aunque lo cierto es que se produciría en un consumo 
excesivo, ya que la graduación de la cerveza no es tan alta como en el caso de las bebidas espirituosas. Del mismo modo, se establece que se podrá resaltar el placer de la comunicación, pero no indicar que consumir estos productos te hace un fracasado, sin éxito social, etc. Lo cierto es que encontramos la misma contradicción que en el código anterior, ya que en este tipo de anuncios aparecen personas guapas, con clase, divirtiéndose, con amigos y con unos novios o novias espectaculares. De esta forma, el mensaje sería si bebes esto, serás así, que es el formato de mensaje de la publicidad actual, y que nosotros estamos cuestionando a lo largo de esta investigación.

Por último, valoramos las medidas en el caso de la protección de los menores, y por el contrario, criticamos, al igual que en caso anterior, que el mensaje de consumo moderado no aparezca en las proporciones que deberían aparecer para poder ser realmente leído por los consumidores.

\section{Código de autorregulación del vino en materia de publicidad y comunicaciones comerciales}

En el Código de Autorregulación del vino ${ }^{19}$ en materia de publicidad y comunicaciones comerciales se establece la importancia que tiene el vino desde el punto de vista social y cultural, económico y medioambiental y por ello quieren, con este código quieren poner de manifiesto la responsabilidad social que tienen con los consumidores y fomentar un consumo responsable. Este código se aprobó en el año 2009 y se articula en siete capítulos, siendo el segundo el dedicado a los principios generales (12 en total).

\footnotetext{
${ }_{19}$ Código de autorregulación del vino en materia de publicidad y comunicaciones comerciales. Página web Autocontrol.
} Consultada 1-2-2010 en http:/ / www.autocontrol.es/pdfs/pdfs_codigos/CODIGOFEV.pdf 


\subsection{Principios del Código de Autorregulación del vino en materia de publicidad y comunicaciones comerciales}

Respeto a la ley vigente.

En este código se establece que "las comunicaciones comerciales sobre vinos se ajustarán a la legislación vigente, cualquiera que sea su contenido, el medio de difusión o forma que adopte" (Cap. 4 ).

Respeto y protección al consumidor.

Al igual que ocurría en otros códigos, en éste no se hacen referencias explícitas al respeto al consumidor, pero podemos deducirlas de otros artículos en los que se habla de la necesidad de una comunicación veraz y del concepto de responsabilidad social que ponen de manifiesto como causa directa de este tipo de código.

Características del mensaje.

- "Las comunicaciones sobre vinos serán decentes, honestas y verídicas" (Cap. $4)$.

- Deben incluir el mensaje de consumo moderado, que ocupará el uno por ciento del total del anuncio. En el caso de la televisión y del cine éste durará dos segundos y ocupará el 1'5 por ciento de la superficie del anuncio (Cap. $5.1)$.

- No deben fomentar un consumo abusivo del producto, ni deben evocar el miedo. Tampoco deben asociarse con situaciones violentas (Cap. 5.2 ).

- Los mensajes deben ser claros y comprensibles (Cap. 5.3). 
- "Las comunicaciones comerciales no deben sugerir que la abstinencia es asimilable a la inmadurez" (Cap. 5.4 ). Tampoco deben reivindicar el efecto desinhibidor del consumo de vino, sugerir que ayuda a superar la timidez y el miedo, que pueda ayudar a solucionar problemas de adaptación (Cap. 5.9 ), que contribuya al éxito social (Cap. 5.11 ) o que aumente la capacidad sexual (Cap. 5.12 ).

- “Las comunicaciones comerciales no deben asociar el consumo de vinos con la conducción" (Cap. 5.4 ).

Normas sobre la inserción de los anuncios.

“Las comunicaciones comerciales no deben ser transmitidas por los medios de comunicación específicamente destinados a los menores en términos de contenido editorial y/o público" (Cap. 5.4 ).

Relación con otras empresas del mercado.

Estas comunicaciones cumplirán las exigencias de buena fe y práctias comerciales" (Cap. 4 ).

Protección de niños y de adolescentes.

\footnotetext{
“Las comunicaciones comerciales no deben ser destinadas a los menores ni mostrar a los menores consumiendo o fomentando el consumo de vinos por menores" (Cap. 5.4 ).
} 


\subsection{Reflexiones sobre el Código de Autorregulación del vino en materia de publicidad y comunicaciones comerciales}

En este código podemos hacer extensible el comentario realizado en los dos anteriores, tanto el de la cerveza como el de las bebidas espirituosas, ya que los principios que postulan son similares y sus carencias y críticas, por tanto, también.

\section{Código deontológico para la publicidad infantil}

El Código para la Publicidad Infantil ${ }^{20}$ fue elaborado por iniciativa de la Asociación Española de Fabricantes de Juguetes y Unión de Consumidores de España. Fue aprobado el 9 de junio de 2003 y se autodefine como un código más ilustrativo que restrictivo, que pretende proteger a los menores. En lo que sería el preámbulo este código- al que se suman seis directrices- se resalta la idea de que "la publicidad puede jugar un papel en la educación infantil" y de ahí la necesidad de un respeto y cuidado máximo a los menores por parte de la publicidad.

En este código también se explica que "los anunciantes deben tener siempre en cuenta el nivel de conocimiento, sofisticación y madurez de la audiencia a la dirigen su mensaje principalmente. Los niños más pequeños poseen una capacidad limitada para evaluar la credibilidad de la información que reciben. Por tanto, los anunciantes tienen que ser responsables a la hora de proteger a los niños de sus propias sensibilidades. Añade, como otro aspecto a tener en cuenta, que debido a la influencia de los padres en el desarrollo de los hijos, "los anunciantes deberían contribuir a desarrollar la relación padre-hijos de una manera constructiva". Vemos como este código, en el que se

20 Código deontológico para la publicidad infantil. Página web Autocontrol. Consultado 10-11-2009 en

http://www.autocontrol.es/pdfs/pdfs_codigos/Cod.\%20(AEFJ).pdf 
plasman claramente las características de los menores (falta de experiencia, carácter intuitivo, etc), ya nos ofrece en el preámbulo alguno de los rasgos que lo definirán como un código hecho con responsabilidad social y que pretende ser de utilidad y de defensa a los menores.

\subsection{Principios del Código deontológico para la publicidad infantil}

En este texto se establecen once principios generales, llamados directrices, que pretenden reflejar cómo debe ser la publicidad dirigida a menores. En cualquier caso, se especifica que "cuando no exista una directriz específica con relación al tema que se trate, habrá que aplicar estos principios en un sentido amplio para evaluar la publicidad dirigida a esa audiencia tan influenciable y tan vulnerable como es la infancia" (Preámbulo). Estas directrices irán dirigidas a los anunciantes que se dirijan a menores de quince años por cualquier medio de comunicación .

A continuación vamos a analizar las once directrices que componen este código. Respeto a la ley vigente.

En este código se plasma el respeto a la legalidad vigente (Preámbulo).

Respeto y protección al consumidor.

En este caso, el consumidor es el niño y a lo largo de este código hay numerosas manifestaciones explícitas sobre la necesidad de protegerlo y de respetarlo, como se puede comprobar a lo largo de sus principios.

Características del mensaje.

De entre las muchas características que debe cumplir el mensaje publicitario dirigido a los niños, nosotros extraemos las siguientes, y lo hacemos basándonos en el criterio de novedad, fundamentalmente: 
- “La presentación publicitaria no debería equivocar a los niños sobre los beneficios derivados del uso del producto. En ellos podría señalarse, aunque la lista no es exhaustiva: la adquisición de fortaleza, estatus, popularidad, crecimiento, habilidad o inteligencia" (Directriz 1). En este mismo sentido, añade que "la publicidad no debe dar la impresión de que poseer un producto dará una mayor aceptación del niño entre sus amigos (...) Los anuncios no deben sugerir que la compra y el uso del producto aportarán al usuario el prestigio, las habilidades y otras cualidades especiales de los personajes que aparecen en el anuncio" (Directriz 3).

- En relación con los padres, se afirma que "no se debe instar a los niños a que pidan a sus padres o a otras personas que les compren los artículos" y "no deben sugerir que un padre o un adulto que compra un producto o un servicio a un niño es mejor, más inteligente o más generoso que el que no lo hace" (Directriz 3). Añaden que no se debe someter a los menores a una presión comercial extrema (Directriz 3).

- Además, señala que la publicidad debe ser claramente identificable, real que las características del producto en el anuncio se correspondan con la realidad-, no deben introducir ninguna referencia a la violencia (Directriz 1) y debe ser fácilmente comprensible por parte de los pequeños (Directriz 4).

- También, la publicidad debe presentar los productos utilizándose con seguridad y a ello se dedica una directriz completa (Directriz 11).

Relación con otras empresas del mercado.

Una de las directrices está dedicada a la publicidad comparativa y se establece que, en el caso de que se diera, debe hacerse basándose en características reales y siendo de total comprensión para los niños (Directriz 5). 


\subsection{Reflexiones sobre el Código para la Publicidad Infantil}

La publicidad infantil constituye uno de los apartados de este trabajo. Por eso, hemos prestado especial atención a este código ético. Lo consideramos, tras haber conocido sus principios, un código bastante completo y que intenta regular al máximo la publicidad infantil, con el ánimo de proteger realmente a los menores. Incluye el respeto a la legalidad vigente, la defensa de una publicidad honesta y veraz, la oposición al fomento de la violencia y la necesidad de identificar bien la publicidad.

Uno de los aspectos que nos gustaría comentar es la idea que de un anuncio no debe sugerir al niño que el poseerlo le hará más feliz, más aceptado socialmente, con más amigos, etc, algo que vemos que no se cumple en la publicidad real. En cualquier anuncio de juguetes podemos ver a niños muy felices, sonrientes, incluso con amigos, disfrutando de su juguete. Eso da la impresión de que es una consecuencia directa del mismo. En cualquier caso, valoramos que en este código se refleje esta cuestión- que debería reflejarse en todos los códigos éticos - ya que es la estrategia fundamental de la publicidad actual a pesar de que en la realidad no se cumpla demasiado este principio.

Nos gustaría también comentar el aspecto en el que se dice que no se debe instar a los niños a que los padres les compren este juguete. Derivado del aspecto anterior, aunque no se diga explícitamente en el anuncio que el niño pida al padre el producto, al ver las consecuencias tan positivas que tiene para él el mismo, no dudará en pensar que si su padre lo quiere, le comprará ese juguete.

También podemos destacar de este código el apartado en el que se afirma que no se debe someter al menor a un presión comercial extrema. Consideramos que la emisión de bloques completos de anuncios infantiles, sobre todo en época de Navidades es claramente presión comercial. En este sentido, quizá este código debería establecer a partir de cuántos anuncios se considera presión comercial. En cualquier caso, volvemos a ver un aspecto de este código que no se cumple. 
Como conclusión a este análisis, debemos afirmar que este código, como decíamos al principio, es bastante completo y defiende con gran rigor a los menores. Introduce principios novedosos, que no veremos en ningún código ético y que deberían hacerse extensibles a los mismos. En cualquier caso, sólo con ver algunos de los anuncios del sector de los juguetes, podemos observar que los principios aquí establecidos no se cumplen en la mayoría de las ocasiones y esto es la consecuencia del propio carácter ético del mismo, que lo hace voluntario.

\section{Código de autorregulación de la publicidad de alimentos dirigida a menores, prevención de la obesidad y la salud}

El Código de Autorregulación de la Publicidad de alimentos ${ }^{21}$ dirigida a menores, prevención de la obesidad y la salud fue aprobado el 25 de marzo de 2005. Está en el marco de la estrategia Naos, lanzada por el Ministerio de Sanidad y Consumo y cuyo objetivo es "disminuir la prevalencia de obesidad y sobrepeso y sus consecuencias, tanto en el ámbito de la salud pública como de sus repercusiones sociales" (Introducción).

Este código se aplica a los menores, exigiendo una mayor cautela en los mensajes publicitarios dirigidos a menores de hasta doce años, algo que se establecerá en función del tipo de producto, el diseño y la circunstancias en las que se lleva a cabo la difusión del mensaje publicitario. El texto se articula en doce principios, introducción y ámbito y normas de aplicación.

\footnotetext{
${ }_{21}$ Código de Autorregulación de la publicidad de alimentos dirigida a menores, prevención de la obesidad y la salud. Página web Autocontrol. Consultada 10-02-2010 en http://www.autocontrol.es/pdfs/cod_\%20Paos.pdf
} 


\subsection{Principios del Código de autorregulación de la Publicidad de alimentos dirigida a menores, prevención de la obesidad y la salud}

Respeto a la ley vigente.

En este código se afirma que "la publicidad de alimentos y bebidas dirigidas a menores se ajustará a la legislación vigente, cualquiera que sea su contenido, el medio de difusión o la forma que adopte" (art. 1 ).

Respeto y protección al consumidor.

Aunque no existen referencias exactas respecto a la protección del consumidor, podemos afirmar que este principio es el que rige todos los criterios establecidos, como se puede observar. Por tanto, afirmamos que sí está presente el concepto de respeto y protección al consumidor.

Características del mensaje.

- En este código se recuerda que "los menores se caracterizan por tener una menor experiencia y una mayor credulidad e ingenuidad", por lo que “mensajes publicitarios que en condiciones normales resultarían claros y veraces para un público adulto, podrían ser considerados engañosos si su público destinatario es menor de edad" (art. 3 ).

- El anuncio debe usar un lenguaje comprensible por los niños y se evitará que las comunicaciones publicitarias puedan inducir a errores a los pequeños. Añaden que no se debe sugerir que los productos tienen características 
particulares, cuando todos los productos similares poseen tales características (art. 3 ).

- No se debe inducir a error al destinatario, ni sobre sus características ni sobre sus beneficios. Añaden que no se debe explotar la imaginación del menor. Afirman que "la fantasía, incluyendo las animaciones y los dibujos animados, es idónea tanto para los niños más pequeños como para los mayores. Sin embargo, debe evitarse que la utilización publicitaria de tales elementos cree expectativas inalcanzables o explote la ingenuidad de los niños más pequeños a la hora de distinguir entre fantasía y realidad" (art. 3 ).

- La publicidad de alimentos o bebidas no debe hacer un llamamiento directo a los menores a la compra del producto anunciado, explotando su inexperiencia o credulidad, ni incitarles a que pidan ni persuadan a sus padres $\mathrm{u}$ otras personas para que compren los productos anunciados. Estos anuncios tampoco deben sugerir que un padre o un adulto que compra un producto alimenticio o una bebida a un niño es un padre o un adulto mejor, más inteligente o más generoso que el que no lo hace". En este mismo apartado se establece, al igual que en otros códigos de productos dirigidos a menores que, "la publicidad no debe dar la impresión de que adquirir o consumir un alimento o bebida dará una mayor aceptación del niño entre sus amigos. Y al contrario, tampoco debe implicar que o adquirir o consumir un producto provocará el rechazo del niño entre sus compañeros" (art. 5 ).

- No deben utilizares como reclamo personajes relacionados con la infancia (art. 6 ).

- Los mensajes publicitarios deben ser fácilmente identificables (art. 7) y comprensibles de forma clara por los menores (art. 8).

- No se podrá presentar al menor en ninguna situación insegura (art. 10).

- "La publicidad de alimentos o bebidas no deberá minusvalorar la importancia de hábitos de vida saludables, tales como el mantenimiento de 
una alimentación variada y equilibrada o la realización de actividad física (art. 11).

Relación con otras empresas del mercado.

“La publicidad de alimentos y bebidas dirigidas a menores se ajustará a las exigencias de buena fe y los buenos usos mercantiles, cualquiera que sea su contenido, el medio de difusión o la forma que adopte" (art. 2 ).

\subsection{Reflexiones sobre el Código de autorregulación de la publicidad de alimentos dirigida a menores, prevención de la obesidad y la salud}

Al igual que el código anterior, también dirigido a proteger a los menores de la publicidad, consideramos que es un código bastante completo, aunque no quizá tanto como el anterior, que recoge más principios. En cualquier caso, nos parece correcto y con normas de utilidad. Ahora bien, encontramos carencias. De este modo, echamos en falta que se estime y concrete qué es presión publicitaria, así como ciertas normas acerca de la inserción de los anuncios en los medios de comunicación.

Además, y como ya habíamos comentado en el código anterior, también dedicado a la infancia, valoramos los principios en los que se insta a la publicidad a vender el producto o servicio concreto y no cosas inmateriales asociadas a él, pero lo cierto es que sigue sin cumplirse este principio en la realidad publicitaria. 


\section{Código ético para los miembros de Andema (Asociación Nacional para la Defensa de la marca)}

El Código ético para los miembros de Andema ${ }^{22}$ (Asociación Nacional para la defensa de la marca) es un código muy escueto (sólo dos páginas), pero a pesar de ellos vamos a analizarlo. Fue aprobado en el año 2004.

\subsection{Principios del Código ético para los miembros de Andema}

Respeto a la ley vigente.

En este código se establece que la "actividad de los adheridos se desarrollará en el respeto al derecho positivo vigente y a los principios inspiradores del ordenamiento jurídico en materia de propiedad industrial e intelectual" (art. 4).

Características del mensaje.

"Los miembros adheridos deben ejercitar sus derechos de forma coherente y razonable de acuerdo con los principios éticos que exige la conciencia social " (art. 5).

Relación con otras empresas del mercado.

“Se cuidará el respeto a la libre y leal competencia, de acuerdo con las exigencias a la normativa vigente en cada caso" (art. 4).

22 Código ético para los miembros de Andema. Página web Autocontrol. Consultada 2-2- 2010 en

http://www.autocontrol.es/pdfs/pdfs_codigos/Cod.\%20\%28ANDEMA\%29.pdf 


\subsection{Reflexiones sobre el Código ético para los miembros de Andema}

Como podemos observar es, sin duda, el código más pobre de todos los estudiados, ya que sólo hace referencia de forma genérica al respeto a las cuestiones éticas, a la competencia leal y al respeto a la ley vigente. No hace referencia a un aspecto fundamental, para nosotros, como es como es la apropiación de los conceptos inmateriales por parte de las marcas. De esta forma, y siguiendo con nuestro hilo argumental, son las marcas las que, al fin y al cabo, tienen ese aura de conceptos inmateriales - felicidad, etc- que envuelve a sus productos. En este código se podría regular eso y concretar qué tipo de características se deberían asociar con las marcas, es decir, si materiales o inmateriales.

Es éste, por tanto, un código excesivamente escueto que no sabemos a qué criterio responde. Lo que sí sabemos es que su objetivo fundamental no es proteger al consumidor.

\section{Otros códigos éticos}

Junto a todos los códigos éticos que hemos analizado a lo largo de este trabajo, vamos a citar otros códigos realizados en España ${ }^{23}$ que también están en vigor y que no analizamos ya que los criterios que utilizan son similares a los ya estudiados:

- Código de buenas prácticas para el uso de argumentos ambientales en la publicidad comercial. 2009.

\footnotetext{
${ }^{23}$ Asociación para la Autorregulación de la Comunicación Comercial. Página web Autocontrol. Consultada 10-1-2010 en http://www.autocontrol.es
} 
- Código español de buenas prácticas para la promoción de los medicamentos y de interrelación de la industria farmaceutica con profesionales sanitarios. 2008.

- Código español de buenas prácticas de promoción de medicamentos y de interrelación de la industria farmaceútica con las organizaciones de pacientes. 2008.

- Código de Normas Deontológicas para la promoción y publicidad de los medicamentos autorizados sin receta médica no financiados por el Sistema Nacional de Salud y otros productos para el autocuidado de la salud. 2007.

- Código ético de la Asociación Española de Fabricantes y Distribuidores de Productos de Nutrición Enteral. 2006.

- Código entre la Federación Española de Empresas de Tecnología Sanitaria (FENIN) y la Asociación para la Autorregulación de la Comunicación Comercial. 2006.

- Directrices sobre Buenas Prácticas en la Publicidad de Productos de Software Interactivo.2005.

- Código ético de la Asociación Nacional de las empresas de investigación de mercados y opinión pública. 2005.

- Código de la Asociación Nacional de Especialidades Farmacéuticas Publicitarias. 1999.

\section{Comparativa entre los distintos códigos éticos}

A continuación, vamos a establecer una tabla comparativa sobre los diversos códigos éticos estudiados, utilizando como variables las categorías que, previamente, hemos establecido para unificar el análisis de los mismos. Como conclusiones generales a la misma, podemos afirmar que: 
- Prácticamente todos los códigos ponen como primer principio el respeto a la legalidad vigente.

- En todos los códigos se establecen criterios de protección al consumidor, aunque, como hemos visto, en unos se hace con mayor precisión que en otros.

- En todos los códigos éticos se hacen referencias a las características del mensaje, las relaciones con otras empresas del mercado y a la protección de niños y adolescentes.

- No todos los códigos éticos establecen normas sobre la inserción de los anuncios.

- Sólo el código de conducta publicitaria trata el tema de la interpretación de los anuncios y de la protección al medio ambiente.

Como decíamos, ésta es una comparativa general, que nos permite - de acuerdo a las categorías que previamente hemos establecido- conocer cuáles son las líneas generales presentes en los códigos éticos. Ahora bien, en el análisis de cada uno de ellos conocíamos con exactitud el alcance de cada uno de esos criterios y su verdadera utilidad en la realidad publicitaria actual. Como complemento a las mismas y con una visión más general de todos los códigos, podemos afirmar que:

- En todos los códigos está presente el concepto de responsabilidad social, que se convierte en la causa de creación del mismo, según se afirma en todos los códigos. Nosotros cuestionamos ese concepto de responsabilidad social que tienen en ocasiones, a juzgar por las reflexiones que hemos hecho hasta ahora.

- En casi todos los códigos éticos se pone de manifiesto el reconocimiento social que tiene la creación de los mismos, es decir, que está bien visto social y políticamente la creación de los mismos. Por ello, algunos de estos códigos 
tienen como misión fundamental mejorar su imagen social, en vez de proteger al consumidor.

- Casi todos los códigos establecen que la publicidad no debe ser engañosa y debe ser identificable. La veracidad es la máxima presente en todos los códigos analizados. La cuestión es saber qué es veracidad para ellos. En el apartado siguiente estudiaremos esta cuestión.

- Sólo en el Código de Conducta Publicitaria se establece que no se puede atribuir a los productos características que no tienen y que lo distinguen de los productos similares en el mercado. Aunque como decimos, no hacen distinción a las características inmateriales, nosotros consideramos que esas mismas son las únicas ventajas que usa la publicidad, en muchos casos, para diferenciarse de los competidores.

- En los códigos éticos de bebidas con graduaciones alcohólicas- los que reciben más críticas por nuestra parte- se intenta justificar la publicidad que se realiza a través del mismo, en vez de establecer unos criterios que permitan una publicidad más ética. De hecho, se afirma que la publicidad de este tipo de productos podrá realzar el placer de la comunicación, convivencia o confraternización social asociado al consumo responsable pero nunca podrá sugerir que el no consumir es sinónimo de inmadurez, de fracaso en la vida social o laboral o en los negocios o que los no consumidores son menos aceptados o tienen menos éxito que los consumidores. Estas ideas se contradicen.

- En los códigos éticos estudiados no se hace distinción entre las características materiales e inmateriales que se atribuyen a los productos, un elemento muy de moda en la publicidad actual.

- En la realidad, como podremos comprobar más adelante, no se cumplen muchos de los aspectos de estos códigos. Esto se deriva del carácter 
voluntario de estos códigos, tanto en su elaboración como en su cumplimiento.

A continuación, mostramos la tabla comparativa de los criterios utilizados por los diversos códigos analizados.

\begin{tabular}{|c|c|c|c|c|c|c|c|c|}
\hline 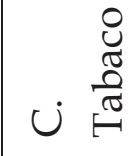 & $\omega$ & ๘ & $\bar{\omega}$ & $\vec{\omega}$ & ○ & Z & $\bar{\omega}$ & Z \\
\hline ن & $\bar{\omega}$ & "ळ & $\bar{\omega}$ & Z & $\stackrel{0}{Z}$ & $\bar{\omega}$ & $\begin{array}{l}0 \\
Z\end{array}$ & $\stackrel{0}{Z}$ \\
\hline ن & $\bar{\omega}$ & $\bar{\omega}$ & $\bar{\omega}$ & Z & Z & $\bar{\omega}$ & $\bar{\omega}$ & Z \\
\hline ن & $\bar{\omega}$ & $\bar{\omega}$ & $\bar{\omega}$ & Z & Z & $\bar{\omega}$ & ๘ & 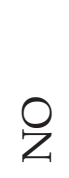 \\
\hline 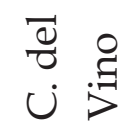 & $\bar{\omega}$ & $\bar{\omega}$ & $\omega$ & $\omega$ & そ & $\bar{\omega}$ & $\bar{\omega}$ & Z \\
\hline 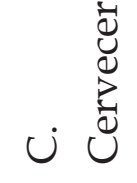 & $\varpi$ & ๘ & $\bar{\omega}$ & $\vec{\omega}$ & $\begin{array}{l}\text { O } \\
\text { Z }\end{array}$ & $\bar{n}$ & $\varpi$ & $\stackrel{0}{Z}$ \\
\hline ن & $\varpi$ & ๘ & $\bar{\omega}$ & $\bar{\omega}$ & Z & $\bar{\omega}$ & $\varpi$ & Z \\
\hline 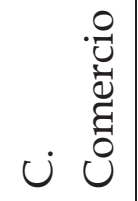 & ๘ & $\bar{\omega}$ & $\vec{\omega}$ & $\bar{\omega}$ & Z & $\bar{\omega}$ & ๘ & 吕 \\
\hline
\end{tabular}




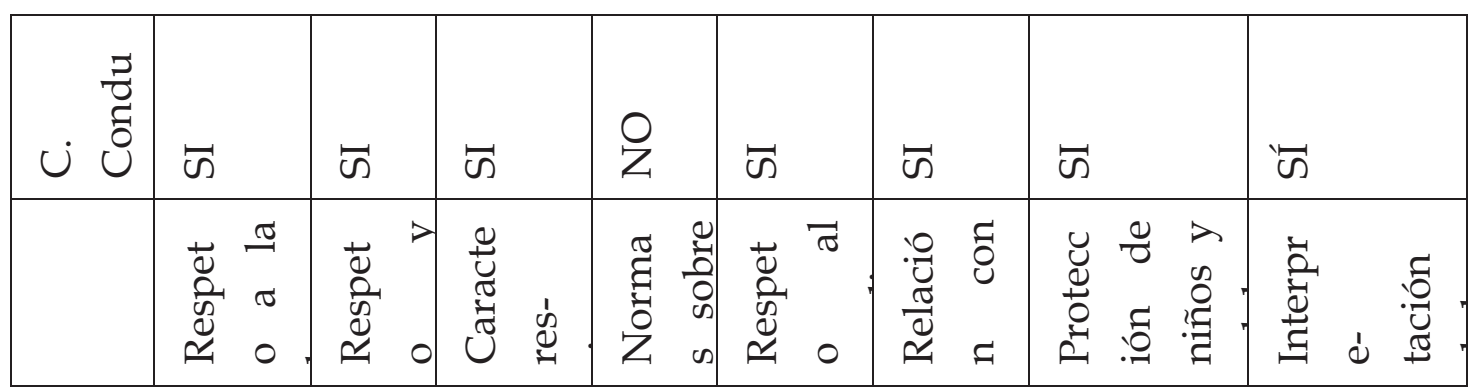

\section{Elaboración de nuestro propio código ético para las comunicaciones comerciales}

A tenor de lo expuesto anteriormente en el análisis de los códigos éticos y teniendo en cuenta los criterios que utilizan y los que deberían utilizar, a nuestro juicio, nos atrevemos a realizar nuestro propio código ético. Éste sería válido para todo tipo de comunicaciones comerciales y engloba los principios más interesantes y útiles de los códigos vistos hasta ahora, acompañados de otros establecidos por nosotros a tenor de las carencias observadas en los mismos.

Capítulo 1: Respeto a la ley vigente

Art. 1: “La publicidad debe respetar la legalidad vigente y, de manera especial, los valores, derechos y principios reconocidos en la Constitución (art. 2)".

Capítulo 2: Respeto y protección al consumidor

Art. 2. La Publicidad no debe abusar de la buena fe del consumidor, entendiendo por tal la credibilidad que le otorga a la publicidad. De esta forma, la publicidad debe responder de forma clara y precisa a las expectativas creadas por ella al consumidor.

Capítulo 3: Características del mensaje

Art. 3. La publicidad debe ser identificable, honesta y veraz. No debe, por tanto, ser engañosa, entendiendo por tal aquella que induzca a error a sus destinatarios. De este 
modo, la publicidad no podrá prometer características o ventajas que no sean comprobables.

Art. 4. El mensaje publicitario deberá ser siempre comprensible.

Art. 5. La publicidad no ofrecerá argumentos que se aprovechen del miedo, temor o supersticiones del destinatario, sea en el ámbito psicológico - incluyendo aquí el ámbito personal y social- o físico. Esta práctica sólo será pertinente cuando el objetivo sea alentar comportamientos seguros y prudentes, como en el caso de las campañas de la Dirección General de Tráfico.

Art. 6. La publicidad no sugerirá circunstancias de discriminación, ya sea por razón de raza, nacionalidad, religión, sexo u orientación sexual, ni atentará contra la dignidad de la persona". Tampoco utilizará la imagen de la mujer, ni de cualquier colectivo, de forma estereotipada.

Art. 7. La publicidad no incitará a la violencia, ni incluirá elementos que atenten contra el buen gusto y decoro social.

Art. 8. Los anuncios deben estar acompañados de la información necesaria y exacta para el consumidor, tales como las características o ventajas del producto, lugar donde se puede adquirir, empresa y precio (este último será opcional), ya que ése es el elemento principal que da lugar a la compra por parte del consumidor.

Art. 9. En el caso concreto de las bebidas alcohólicas, debe indicarse claramente su graduación. Además, el mensaje de consumo responsable debe tener una tipografía y duración superior a la establecida actualmente, llegando al tres ó cuatro por ciento de la superficie del anuncio y con una duración de más de cinco segundos en el caso de la televisión. La publicidad de este tipo de productos debe estar acompañada por la recomendación de 'Si bebes, no conduzcas', con un tamaño y duración igual que en el caso del mensaje de recomendación de consumo moderado. 
Capítulo 4: Protección al medio ambiente

Art. 10. La publicidad no incitará ni alentará comportamientos que perjudiquen el medio ambiente.

Capítulo 5: Interpretación de los anuncios

Art. 11: Los anuncios y las expresiones publicitarias deben ser analizadas en su conjunto, atendiendo a la impresión global que generen en sus destinatarios, aunque podrán ser objeto de análisis específico aquellas partes que, por aparecer de forma especialmente destacada, capten principalmente la atención del consumidor. Ésta será la manera de analizar los anuncios para aplicar los principios expuestos en este código.

Capítulo 6: Normas sobre la inserción de los anuncios

Art. 12. Las normas de inserción de los anuncios en los medios serán similares para todo tipo de anuncios, excepto en los dos casos siguientes:

1. En el caso de productos dirigidos a mayores de 18 años- como es el caso de las bebidas alcohólicas, por ejemplo.

2. La publicidad dirigida a menores.

Las normas concretas de este artículo se establecerán a tenor de los resultados del estudio sobre audiencia que debe realizarse.

Capítulo 7: Relación con otras empresas del mercado.

Art. 13. La publicidad no deberá contener referencias a los signos distintivos de otro anunciante ni de otros anuncios .

Art. 14. La publicidad no deberá denigrar ni menospreciar a otras empresas, actividades, productos o servicios.

Capítulo 8: Protección de niños y de adolescentes 
Art. 15. La publicidad dirigida a niños deberá ser extremadamente cuidadosa y no debe explotar la ingenuidad, inmadurez e inexperiencia de los niños, ni abusar de su sentido de la lealtad.

Art. 16. No se deberá incitar directamente a los menores a la compra de un producto o servicio, explotando su inexperiencia o su credulidad, ni a que persuadan a sus padres o tutores para que compren los productos o servicios de que se trate.

Art. 17. La publicidad dirigida a menores debe ser especialmente cuidadosa para no equivocar a los niños sobre los beneficios que supone la utilización del producto anunciado.

Art. 18. No debe someterse a los menores a una presión comercial extrema, aspecto que será concretado tras el estudio pertinente acerca del tema.

En este código están recogidos todos los principios éticos que debe cumplir la publicidad y por los que nosotros abogamos en esta investigación. Sólo hemos dejado sin concretar dos aspectos: el relativo a las normas de inserción y a la presión comercial, ya que no tenemos los datos necesarios para fijar unos criterios exactos. De ahí que solicitemos la elaboración de un estudio sobre estos dos aspectos. En cualquier caso, y como explicábamos al principio, este código puede ser general para todo tipo de actividades comerciales, ya que recoge los criterios básicos que se deben seguir y que se resumen en uno: la veracidad de la publicidad.

\section{BIBLIOGRAFÍA}

\section{$\underline{\text { Libros }}$}

- Aznar, Hugo: Comunicación responsable. Barcelona. 1999. Ariel.

- Bonete, Enrique: Ética de la comunicación audiovisual. Madrid. 1999. Tecnos.

- Jareño, Joaquín: Ética y periodismo. Urduliz, País Vasco. 2009. Desclée. 
- Ortega, Enrique: La comunicación publicitaria. Madrid.2004. Editorial Pirámide.

- Ramos, Fernando: La publicidad contaminada. Madrid. 2003. Universitas.

- Sánchez Guzmán, José Ramón: Teoría de la Publicidad. Madrid. 1993. Editorial Tecnos.

Códigos éticos

- Asociación para la Autorregulación de la Comunicación Comercial. Página web Autocontrol. Consultada 10-1-2010 en http:// www.autocontrol.es

- Código de la Febe. Página web Autocontrol . Consultada 6-1-2010 en http://www.auto-control.es/pdfs/pdfs_codigos/cod0017.pdf

- Código de conducta publicitaria. Página web Autocontrol. Consultada 20-1-2010 en http://www.autocontrol.es/pdfs/Cod_conducta_publicitaria.pdf

- Código ético de comercio electrónico. Página web Autocontrol. Consultada 25-1-2010 en http://www.autocontrol.es/pdfs/Cod_ConfianzaOnline.pdf

- Código de autorregulación publicitaria de cerveceros de España. Página web Autocontrol. Consultada 23-1- 2010 en http://www.autocontrol.es/pdfs/pdfs_codigos/cod0036.pdf

- Código de autorregulación del vino en materia de publicidad y comunicaciones comerciales. Página web Autocontrol. Consultada 1-2-2010 en http://www.autocontrol.es/pdfs/pdfs_codigos/CODIGOFEV.pdf

- Código de Autorregulación de la publicidad de alimentos dirigida a menores, prevención de la obesidad y la salud. Página web Autocontrol. Consultada 10-02-2010 en http://www.autocontrol.es/pdfs/cod_\%20Paos.pdf

- Código ético para los miembros de Andema. Página web Autocontrol. Consultada 22- 2010 en

http://www.autocontrol.es/pdfs/pdfs_codigos/Cod.\%20\%28ANDEMA\%29.pd $\underline{f}$ 